\title{
SPL Blood and Tissue Form Terminology
}

National Cancer Institute

\section{Source}

National Cancer Institute. SPL Blood and Tissue Form Terminology. NCI Thesaurus.

Code C133239.

A category of terminology used to qualify the information pertaining to blood and tissue forms in the framework of the Structured Product Labeling documents. 